\title{
Cultivation of Cross-Cultural Communicative Competence of Higher Vocational Students
}

\author{
Kun $\mathrm{Li}^{1}$, Hewei Fu${ }^{1}$, Ximu Yan ${ }^{1}$ \\ ${ }^{1}$ Qinhuangdao Institute of Technology, Qinhuangdao, Hebei, China \\ hunter2011@foxmail.com
}

Keywords: Higher vocational students, Cross-cultural commination, Communicative competence

\begin{abstract}
With the continuous development of economic globalization, higher vocational colleges should not only strengthen the students' vocational training, but also should try to improve students' cross-cultural communicative competence.This paperfirstly expounds the necessity of the cultivation of intercultural communication ability in higher vocational colleges, then discusses the present situation of the education of intercultural communication, and finally provides some corresponding measures in order to improve the vocational students' intercultural communication ability.
\end{abstract}

\section{Introduction}

Intercultural communicative competence is one of the essential abilities of higher vocational students. China and the West have some significant differences in the cultural background, the political position, the outlook on life and the values. These differences require that higher vocational students should not only have fluent oral English, but also have the ability of cross-cultural communication. To meet the needs of the international pattern of talents, we should continuously strengthen the cultivation of higher vocational students' intercultural communicative competence to improve the communication level with foreign students.

\section{Necessity of Cultivation of Cross-Cultural Communicative Competence}

With the globalization of economic development, the rate of higher vocational students' joining in foreign enterprises, learning in abroadcountries, traveling in alien areas is increasing fast. Even in the main direction of the future employment of higher vocational students, that is private enterprises and state-owned enterprises, the number of expatriates in the service is increasing year by year. Therefore, in the daily work and life of the exchange, and the people cannot avoid communication with foreigners. The cultivation of cross-cultural communication skills is imperative.

With the promotion of China's international status, China's participation in international activities, such as the Beijing Olympics, Asian Games, World Expo, etc., these activities need to avoid the need to deal with different cultural backgrounds, intercultural communication ability in these international exchanges is particularly necessary. At present, a lot of activities belong to a kind of cross-cultural communication. Each country is different, if it is standing in the position of their own national culture, according to their own cultural understanding and communication. It may lead to the culture conflict and the big failure of the event when serious. Intercultural communicative competence has become one of the essential qualities of higher vocational students. Higher vocational colleges can not only pay attention to the cultivation of practical ability, but also strengthen the ability of English communication, especially cross-cultural communication skills, a clear understanding of the meaning of foreign people, the cultural practices of the British and American English, listening to the sound of English. Cross-cultural communication is a very prominent point in modern times. In fact, the daily communication is an invisible cross-cultural communication. Cross cultural communication to the whole process of the foreign exchange and every link. Therefore, in order to meet the needs of English talent in the world, students in higher vocational colleges should not only master their own traditional culture, but also master the western countries, the customs, culture, history, geography and so on.In the training of professional 
technical personnel, we must pay attention to the cultivation of intercultural communication ability to improve the comprehensive quality of English talent.

\section{Present Situation of the Cultivation in Vocational Higher Colleges}

Nowadays, the situation of the cultivation of cross-cultural communicative competence in vocational higher colleges mainly includes the two aspects of deficiency of teachers' ability and insufficient of students' willingness.

Deficiency of Teachers'Ability. At present, most of the English teachers' intercultural communication awareness is relatively weak. Because their professional and intercultural communication and the British and American culture are not related, they are not familiar with the specific content of cross-cultural communication. Moreover, as the foreign exchange opportunities in higher vocational colleges are relatively few, most of the English teachers' intercultural communication ability is weak. Therefore, they are easy to ignore the cultivation of students' intercultural communicative competence in higher vocational English teaching. English teachers in higher vocational colleges have little practical experience, some teachers only have a short time of enterprise practice experience, these teachers do not have a specific understanding of the requirements of the current higher vocational English proficiency, resulting in the teaching activity has not really pay attention to the cultivation of intercultural communication ability. Although many high vocational English teachers' theoretical knowledge is very solid, but because of lack of cross cultural communication ability of professional background, the relevant enterprise work experience and the full exchange of experience, and the school also don't not set up the corresponding practical skills training courses, so teachers can only use the translation teaching method for vocational English teaching. As the translation teaching mode lacks of vivid images and specific cases, it is alsodifficult to master the knowledge for students.

Insufficiency of Students' Willingness. The current higher vocational English teaching methods are still based on the teaching of teachers, whether it is theoretical knowledge or cultural knowledge. Students are mainly passively received the theoretical knowledge or cultural knowledge. However, due to the difference of eastern and Western cultures, resulting in students in the cramming teaching method is very difficult to truly understand the cross culture knowledge. Even though they have learned the theory of knowledge, it is hard to put them into practice. At present, a lot of students are concerned about the future of employment, not concerned about the arts, literature, diplomacy, education, society, religion, history, geography, politics and other aspects of knowledge, but also do not understand the cultural awareness in the west, which has restricted the formation and development of intercultural communication. Some students only learn the words and grammar of Higher Vocational English, seldom take the initiative to learn the information of current events and culture in their spare time. Although some of the students have a strong practical skills. They have the ability to use English, but they are not capable of using English. Due to the lack of knowledge of Chinese and Western cultural differences, some students have good English communication skills, but it is a lack of understanding of Chinese and Western culture, it is easy to appear some cultural conflicts, which leads to the occurrence of intercultural communication barriers.

\section{Countermeasures of the Cultivation in Vocational Higher Colleges}

Expand Classroom Knowledge. The current English teaching material in the knowledge structure is relatively simple and the content is relatively thin. Therefore, teachers should pay attention to the teaching of English, should pay attention to the appropriate expansion, not only should pay attention to the grammar, vocabulary, vocabulary teaching, but also to expand some of the western culture, intercultural communication related knowledge. In the classroom, teachers can teach students individually as a special chapter to students, and also can be used in the western culture in each lesson, in order to make students accept the western culture, and to cultivate students' intercultural communication consciousness, so as to improve the students' intercultural 
communicative competence. At the same time, the culture teaching should have the stage. The teachers should pay attention to the teaching of the stage. Stage teaching is the teaching of the teachers according to the characteristics of the students. At first, the language skills of the students should be mainly trained, and the content of the culture can be added. When the higher vocational students' English levelsreach a certain extent, the teachers can add more content of the western culture to improve the higher vocational students' intercultural communication ability.

Optimize Curriculum Arrangement. The optimization of the curriculum arrangement means that the teachers should not only expand the contents of the classroomknowledge, but also shouldoptimize the curriculum arrangement so that the English curriculum is more in line with the characteristics of students learning. At present, the students' basic knowledge of English theory is relatively strong, but the actual intercultural communication ability is very weak. Teachers can guide students to make full use of time, read some of the comments, literary classics, English magazines, English newspapers, etc., these materials not only have fun, but also covers the cultural characteristics of various countries, higher vocational students are more willing to accept, in this process students' reading ability can be improved, but also to the national culture has a certain understanding. English programs on $\mathrm{TV}$ and radio can be used as an important source of extra-curricular culture knowledge. Because of the limitation of the time, teachers can encourage students to listen to and watch English after class. In addition, teachers can also open a weekly English club. The weekly clubs set a theme, invite foreign teachers participate. It lets students to speak outto improve the students' ability of oral English and intercultural communicative competence. Teaching and research section can also organizesome lectures. Lectures mainly include a series of reports of the British and American culture.According to the content of the lecture, the section can hold prize competition activities to improve the enthusiasm of the higher vocational students' participation.

Stimulate Students'Interest. With the continuous development of modern education, teachers' teaching mode is changing constantly. Teachers can use modern multimedia technology to change the traditional mode of education, in order to stimulate students' interest. Using teaching software, can be illustrated, higher vocational students' enthusiasm for learning can effectively stimulate; through the Internet, students can learn more rich cultural information, through the establishment of virtual activity, can help students to cultivate intercultural communicative ability. Teachers in the actual teaching can combine multiple channels to carry on teaching, and let students have a more profound understanding of the world's customs, culture, geography, history and other culture. The higher vocational students can enhance the learning abilityof American culturein the process of appreciation of the films and television. The theme of Europe and the United States is more extensive, which will involve a lot of different emotional expression, the relationship between people, social status, cultural background, etc., will be shown in different forms in the film, so in teaching, teachers can use more than the European and American television data to improve students' language skills, and deepen higher vocational students in western countries, behavior patterns, thinking mode. When teachers appropriately use modern education means and equipment, it can greatly stimulate students' learning interest, and more conducive to the cultivation of students' intercultural communication ability.

Improve Teachers' Quality. At present, the English teaching is mainly related to the theoretical knowledge and English skills but not the cultural content, cultural content, including values, politics, religion, language, etc. The cultural differences will have different ways of communication, thinking, customs, language, etc., resulting in the business value will not be consistent. In the current English teaching of higher vocational colleges, teachers are very difficult to grasp the cultural knowledge, can only carry out some simple, scattered cultural knowledge. When it comes to the relevant cultural knowledge, the teacher is only for the higher vocational students to understand the text as a supplement to the background of the teaching, and neglect the students' intercultural communicative competence. Teachers' intercultural communicative competence teaching level directly affects the cultivation of students' intercultural communicative competence.Therefore, we should pay attention to the improvement of teachers' comprehensive 
quality. First of all, teachers should change their ideas, so as to cultivate intercultural communicative competence as an important target of teaching, and to develop effective teaching content according to the characteristics of students, improve students' intercultural communicative competence, and avoid the cultural conflicts in the activities of the students. Teachers should change the teaching mode of "teachers as the center", change the teaching mode of "student oriented", pay attention to the variety, interest and flexibility of teaching method. In addition, teachers should constantly improve their own cultural training, continuously learning the new British and American cultural content and the latest cultural trends to improve the teaching level of cross-cultural communicative competence in vocational higher colleges.

\section{Conclusion}

The globalization of China's economic makes the demand of cross-cultural ability of the higher vocational students increasing fast. The higher vocational students in foreign exchange should not only have fluent spoken language ability, but also should have a certain cross-cultural communication skills. Nowadays, English teachers' intercultural competence is not enough. The students learning willsof cross-cultural communicative competenceare also not strong in the English teaching classroom in higher vocational colleges. Teachers should expand the classroom knowledge, optimize the curriculum arrangement, stimulate students' interest and improve theirown qualities of cross-cultural communicative competence to change the present situation.

\section{References}

[1] Y. Jin, TheInfluencing Factors and Training Strategy of Higher Vocational Students' Cross-Cultural Communicative Competence. Journal of HuBei TV University, 2009, 29(6):33-34.

[2] P. Wang. The Effects of Cross-Cultural Communicative Competence on the Construct of Occupation Qualities of High VocationalCollege Students . Overseas English, 2015 (3):41-42.

[3] P. Feng. Cultivation of Students' Cross-Cultural Communicative Competence in College English Teaching . Journal of Hengshui University, 2015, 17(2):123-125.

[4] M. Chen. Study on Students' Cultivation of Cross-Cultural Communicative Competence at Vocational Level . Jilin University, 2013. 